\title{
Altered Structure and Expression of the p53 Gene in Human Neuroepithelial Tumors
}

\author{
Kazuo TABUCHI, Kouzou FukuYama, Toshihiro Mineta, \\ Mamoru OH-UCHIDA* and Katsuji HORI*
}

Departments of Neurosurgery and *Biochemistry, Saga Medical School, Saga

\begin{abstract}
The p53 gene, located on chromosome 17p13.1, may be important in the pathogenesis of human neuroepithelial tumors, because it is a tumor suppressor gene and genetic alteration is essential for certain human cells to acquire the neoplastic phenotype. The structure and expression of the p53 gene were investigated in cultured human glioma cells and biopsied specimens of neuroepithelial tumors. Immunocytochemical examination of p53 gene expression revealed positive nuclear staining in six of seven glioma cell lines tested. Sodium dodecyl sulfate-polyacrylamide gel electrophoretic analysis demonstrated unequivocal heterogeneity of migration rate in p 53 bands. Pulse-chase analysis clearly showed an increased half-life of p53 in cultured human glioma cells. These abnormalities are presumably due to genetic alterations in the p 53 gene. Nucleotide substitutions in exon 5,7 , or 8 of the p53 gene could be detected by polymerase chain reaction-single strand conformational polymorphic analysis in four of seven (57\%) human glioma cell lines, and nine of $29(31 \%)$ biopsied specimens of neuroepithelial tumors examined. The present results indicate that genetic alterations in the p 53 gene are responsible for the tumorigenesis of at least some human neuroepithelial tumors.
\end{abstract}

Key words: glioma, medulloblastoma, p53, tumor suppressor gene, genetic alteration

\section{Introduction}

Several genetic alterations are associated with the development of certain human gliomas. ${ }^{13,18,19,22,23,39,47,50)}$ The common alterations are deletions on the short arm of chromosome 17 (17p13.1) and the long arm of chromosome 10. Allelic deletions of chromosome $17 \mathrm{p}$ occur in a wide variety of human neoplasms ${ }^{1,8,15,36,46)}$ such as colon, breast, and lung cancers, strongly suggesting that anti-oncogenes (tumor suppressor genes) on $17 \mathrm{p}$ are involved in the neoplastic process of tumors, and probably in some human glial tumors. ${ }^{13,19,23,39)}$

The p53 gene, a postulated tumor suppressor gene, is located on chromosome $17 \mathrm{p}$ and codes for a cellular 53-kd phosphoprotein (p53) now believed to be essential in the regulation of cell division, as it is required for the transition from phase $G_{0}$ to $G_{1}$ of the cell cycle..$^{9,21,25,26,32\}}$ The p53 was first identified through its interaction with the large $T$ antigen of Simian virus 40 , and was thought to be a dominant oncogene enabling full transformation of ver-

Received February 7, 1992; Accepted April 2, 1992 tebrate somatic cell in combination with an activated ras gene. ${ }^{38)}$ However, it has recently been shown that the p53 in the neoplastic cells is all mutant and the wild-type $\mathrm{p} 53$ suppresses transformation of normal cells. ${ }^{2,14}$ The p53 may therefore act as a tumor suppressor, like the product of the retinoblastoma susceptibility gene. The p 53 gene is possibly responsible for the development of human neuroepithelial tumors.

Here, we report our investigation of the structure and expression of the p53 gene in cultured human glioma cells and biopsied specimens of neuroepithelial tumors.

\section{Materials and Methods}

\section{Cell lines and tumor specimens}

Seven established human glioma cell lines (U251MG, U-373MG, T98G, KMG4, A172, U-118MG, and U-87MG) were used in this study. U-251MG, U373MG, T98G, U-118MG, and U-87MG were obtained from the American Type Culture Collection (Rockville, Md., U.S.A.), and A172 from the Japan Cancer Research Bank (Tokyo). KMG4 was kindly 
donated by Dr. Y. Ushio (Kumamoto University Medical School, Kumamoto). All glioma cells were grown in Modified Eagle's Medium (MEM) supplemented with $10 \%$ fetal bovine serum (FBS) and antibiotics at $37^{\circ} \mathrm{C}$ in a humidified $5 \% \quad \mathrm{CO}_{2}$ atmosphere.

The 29 neuroepithelial brain tumor tissues obtained at craniotomy were fixed with neutral formalin and embedded in paraffin. The histological types of the specimens were eight astrocytomas, 16 glioblastomas, and five medulloblastomas.

\section{Immunocytochemistry}

Subconfluent monolayers of cultured cells were fixed in absolute methanol and air dried. Immunological investigation used mouse anti-p53 monoclonal antibody (MoAb) (ab-2; Oncogene Sci. Inc., Manhasset, N.Y., U.S.A.). Mouse anti-rabbit immunoglobulin G MoAb (Sigma Chemical Co., St. Louis, Mo., U.S.A.) was also used as a negative staining control. Antibody binding was visualized by the streptavidin-biotin immunoperoxidase method using a commercial kit (DAKO-Japan, Kyoto).

\section{Immunoprecipitation and gel electrophoresis}

For metabolic labeling, subconfluent cells were suspended in $2 \mathrm{ml}$ of methionine-free MEM supplemented with $10 \%$ dialyzed FBS. ${ }^{35}$ S-methionine $(250 \mu \mathrm{Ci})$ was added and the suspension incubated at $37^{\circ} \mathrm{C}$ for 3 hours. Radiolabeled cells were lysed in buffer containing $150 \mathrm{mM} \mathrm{NaCl}, 50 \mathrm{mM}$ Tris $(\mathrm{pH}$ 7.5), 1\% NP-40, 1\% sodium deoxycholate, and 1 $\mathrm{mM}$ phenyl methyl sulfonyl fluoride. The cell lysates were incubated with mouse anti-p53 MoAb (ab-1; Oncogene Sci. Inc.) at $4^{\circ} \mathrm{C}$ overnight with constant rotation. Packed protein A sepharose ( $50 \mu \mathrm{l}$; Pharmacia, Uppsala, Sweden) was added and the lysate kept at $4^{\circ} \mathrm{C}$ for 30 minutes with rotation. The immune complex was resuspended in protein sample buffer, heated at $70^{\circ} \mathrm{C}$ for 10 minutes, and then applied to sodium dodecyl sulfate-polyacrylamide gel electrophoresis (SDS-PAGE). Two-dimensional PAGE (2D-PAGE) subjected the immunoprecipitates to isoelectric focusing electrophoresis followed by SDS-PAGE.

\section{Pulse-chase analysis}

Plastic culture plates $(10 \mathrm{~cm}$ in diameter) containing equivalent numbers of cells from different cell lines were labeled with ${ }^{35} \mathrm{~S}$-methionine $(250 \mu \mathrm{Ci})$ for 90 minutes. The radioactive medium was then replaced with medium containing non-radioactive methionine, and the label was chased for the indicated period. At the end of the specific chase period, the cells were processed as described above.

V. Deoxyribonucleic acid (DNA) preparation and polymerase chain reaction (PCR) amplification

High-molecular weight DNA was extracted from the 1\% NP-40 treated nuclear fraction of each cell culture. About $10^{8}$ cultured cells were collected and treated with $7.5 \mathrm{ml}$ of buffer containing $5 \mathrm{mM} \mathrm{NaCl}$, $5 \mathrm{mM}$ Tris- $\mathrm{HCl}$ (pH 7.5), and $0.5 \mathrm{mM} \mathrm{MgCl}_{2}$ for 3 minutes on ice. Ten percent NP-40 was added to $1 /$ 10 volume and gently mixed. Immediately the sample was centrifuged at $3500 \mathrm{rpm}$ for 1 minute, and the pellet dissolved in $10 \mathrm{ml}$ of proteinase $\mathrm{K}$ solution $[100 \mu \mathrm{g} / \mathrm{ml}$ proteinase $\mathrm{K}, 0.2 \%$ SDS, $10 \mathrm{mM}$ Tris$\mathrm{HCl}(\mathrm{pH} 7.5)$, and $10 \mathrm{mM}$ ethylenediaminetetraacetic acid (EDTA)], and incubated at $25^{\circ} \mathrm{C}$ for 24 hours. The solution was extracted with an equal

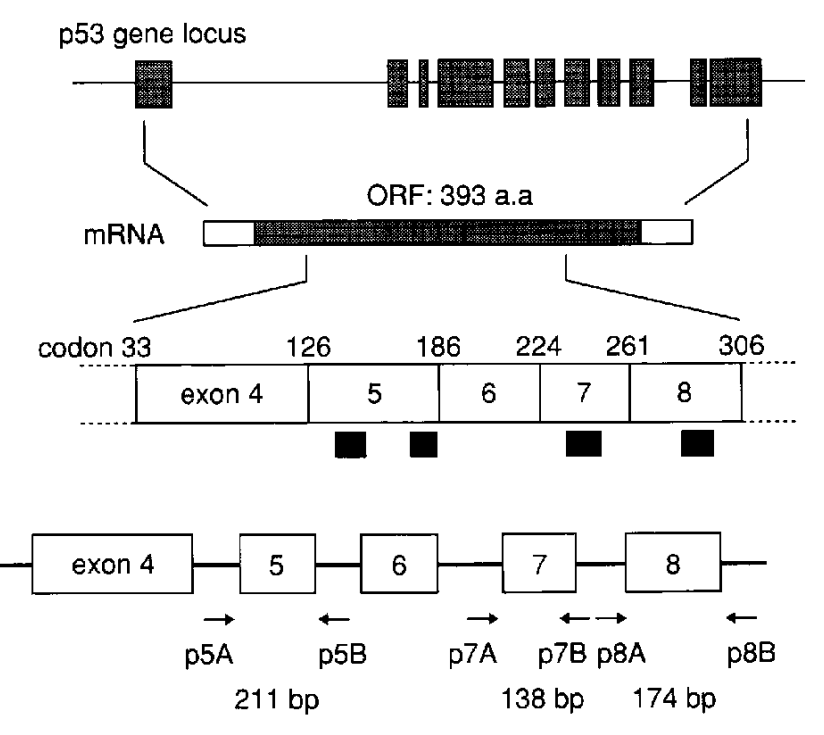

Fig. 1 Scheme of the p53 gene structure and conserved domains. Solid boxes indicate conserved domains, where nucleotide sequences are homologous throughout the species. These domains are supposedly mutational hot regions in a variety of tumors. Three pairs of alleles represent the PCR primers used to amplify the DNA fragments containing the conserved domains. The nucleotide sequences are as follows: p5A, 5'TTCGAATTCCTGCAGTACTCCCCTG; p5B, 5'TAGGATCCGCCCCAGCTGCTCACC; p7A, 5'GTTGAATTCTAGGTTGGCTCTGAC; p7B, 5'CAAGTGGATCCTGACCTGGAGTCTTC; p8A, 5'CGGAATTACCTATCCTGAGTAGTGG; and p8B, 5'ATGGATCCTGCTTGCTTACCTCGC. a.a: amino acid, mRNA: messenger ribonucleic acid, ORF: open reading frame. 
volume of phenol, followed by extraction with an equal volume of chloroform/isoamylalcohol (24:1). Two volumes of ethanol and final $150 \mathrm{mM}$ concentration of $\mathrm{NaCl}$ were added. The high-molecular weight DNA was isolated and dissolved in $1 \mathrm{ml}$ of $10 \mathrm{mM}$ Tris- $\mathrm{HCl}(\mathrm{pH} \mathrm{7.5)}$ and $10 \mathrm{mM}$ EDTA.

For biopsied specimens, three slices of $10 \mu \mathrm{m}$ thick section were cut and deparaffinized with $3 \times 300 \mu \mathrm{l}$ xylene washes. The samples were rinsed three times with $300 \mu \mathrm{l}$ of $70 \%$ ethanol, and the centrifuged pellet was dissolved in $300 \mu \mathrm{l}$ proteinase $\mathrm{K}$ solution ( $100 \mu \mathrm{g} / \mathrm{ml})$ and incubated for $24-48$ hours. DNA was extracted and precipitated as described above. Nearly $5 \mu \mathrm{g}$ of DNA was obtained by this procedure. Extracted DNA was utilized for the PCR consisting of 40 cycles of $94^{\circ} \mathrm{C}(1 \mathrm{~min}), 62^{\circ} \mathrm{C}(1 \mathrm{~min})$, and $72^{\circ} \mathrm{C}$ (1 min). ${ }^{40)}$ The six oligonucleotides were synthesized as PCR primer according to the nucleotide sequences of the introns just anterior and posterior to exon 5, 7 , and 8 of the human p53 gene, which are known to be highly conserved domains throughout the species: p5A, p5B, p7A, p7B, p8A, and p8B (Fig. 1). The PCR reagents were $1.5 \mathrm{mM} \mathrm{MgCl}, 10 \mathrm{mM}$ Tris- $\mathrm{HCl}$, $50 \mathrm{mM} \mathrm{KCl}, 200 \mu \mathrm{M}$ each of deoxy-adenosine triphosphate (ATP), guanosine 5'-triphosphate, cytidine triphosphate, and thymidine 5'-triphosphate, $100 \mathrm{pM}$ of $\gamma_{-}{ }^{32} \mathrm{P}$-deoxy-ATP-labeled primers, and $0.25 \mathrm{U}$ Taq polymerase (Promega Corp., Madison, Wis., U.S.A.).

VI. PCR-single strand conformational polymorphic (SSCP) analysis

The SSCP analysis of PCR products was carried out as follows. Each PCR product was diluted 100 fold with $95 \%$ formamide dye and heated at $95^{\circ} \mathrm{C}$ for 3 minutes to denature the DNA, and then $2 \mu$ of sample was loaded on $6 \%$ neutral polyacrylamide gel $(40 \times 20 \times 0.03 \mathrm{~cm})$. Electrophoresis was carried out at $4^{\circ} \mathrm{C}$ under $40 \mathrm{~W}$ constant power. The gel was transferred to a $0.33 \mathrm{~mm}$ thick cellulose paper (Whatman Ltd., Maidstone, England) and dried, and then autoradiography performed overnight. ${ }^{37}$

\section{Results}

\section{Immunocytochemistry}

Table 1 shows that human glioma cell lines revealed a variety of immunostaining reactions to p53. U87MG cells showed equivocal nuclear staining for p53, while U-118MG, KMG4, and A172 cells were weakly positive. U-251MG, U-373MG, and T98G

Table 1 Altered expression of p53 in human glioma cell lines

\begin{tabular}{lcc} 
Cell line & p53 expression* & p53 half-life \\
\hline U-87MG & + & ND \\
T98G & +++ & prolonged \\
U-118MG & ++ & ND \\
A172 & ++ & prolonged \\
U-251MG & +++ & prolonged \\
U-373MG & +++ & prolonged \\
KMG4 & ++ & ND
\end{tabular}

*Immunocytochemical positivity:,$+ 5-49 \% ;++$, $50-89 \% ;+++, 90-100 \%$. ND: not determined.
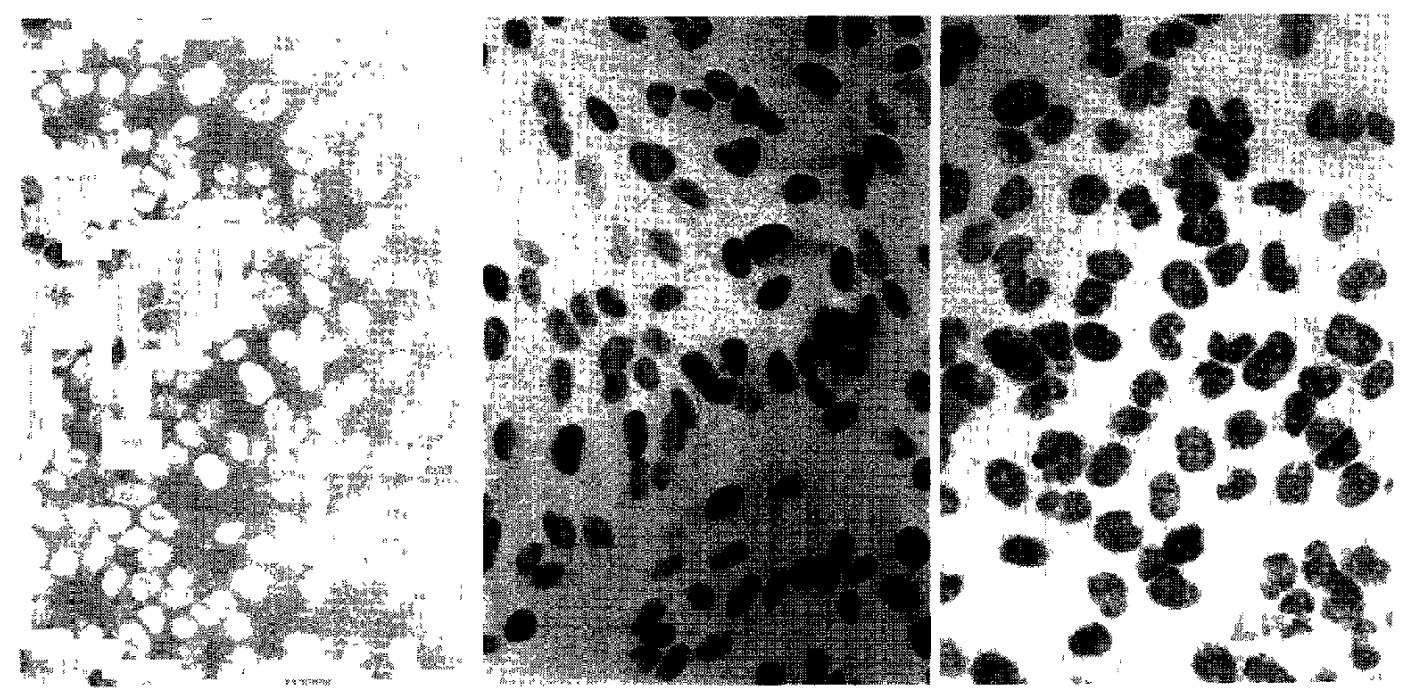

Fig. 2 Immunocytochemical localization of p53 in cultured U-251MG (left), U-373MG (center), and T98G (right) cells. Immunoperoxidase method without counterstain, $\times 400$. 


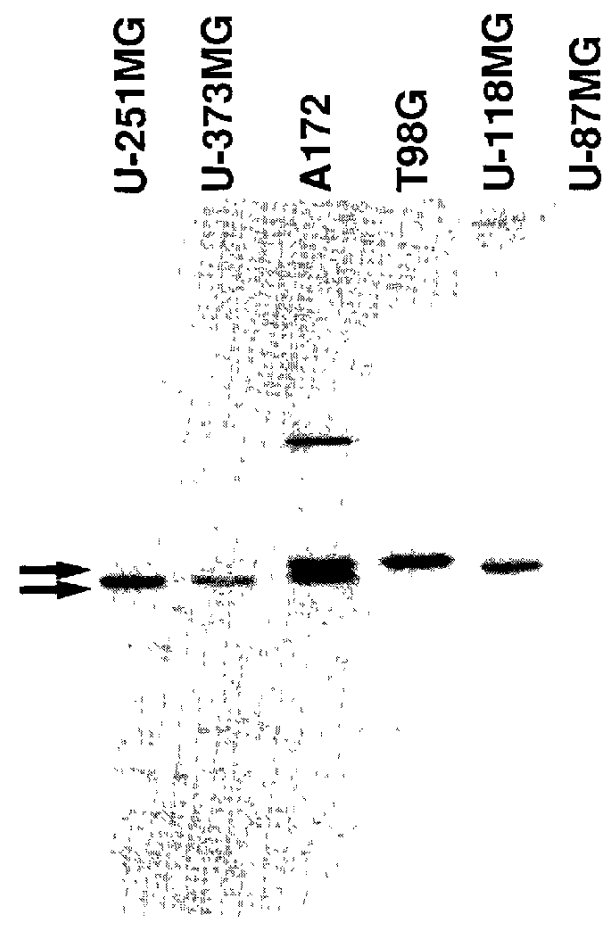

Fig. 3 SDS-PAGE analysis of p53 immunoprecipitates from human glioma cell lines. p53 is detected in all glioma cell lines except for $\mathrm{U}$ 87MG. The positivity for p53 in U-87MG is equivocal, but a faint band is discernible with longer exposure. There is evident heterogeneity in the migration rates of $\mathrm{p} 53$ in a slab gel (arrows). Note A172 cells showing doublet bands.

cells displayed intensely positive nuclear staining for p53 (Fig. 2). The cytoplasm of cultured human glioma cell appeared negative.

\section{Immunoprecipitation and gel electrophoresis}

The SDS-PAGE analysis detected p53 in all human glioma cell lines except for U-87MG. The migration rates of $\mathrm{p} 53$ were slightly different between cell lines (Fig. 3). U-251MG and U-373MG showed a single band for $\mathrm{p} 53$, which migrated faster than those of T98G and U-118MG. A172 in particular revealed doublet bands for $\mathrm{p} 53$. The findings indicate that $\mathrm{p} 53$ expressed in these human glioma cells has heterogeneous molecular conformation and antigenic activity. Further evidence was obtained from 2D-PAGE analysis (Fig. 4). Several spots, all of the same molecular weight, were identified as p53. With A172 cells, there were six different spots for $\mathrm{p} 53$, consisting of three in the fast and three in the slow components, suggesting different isoelectric points.

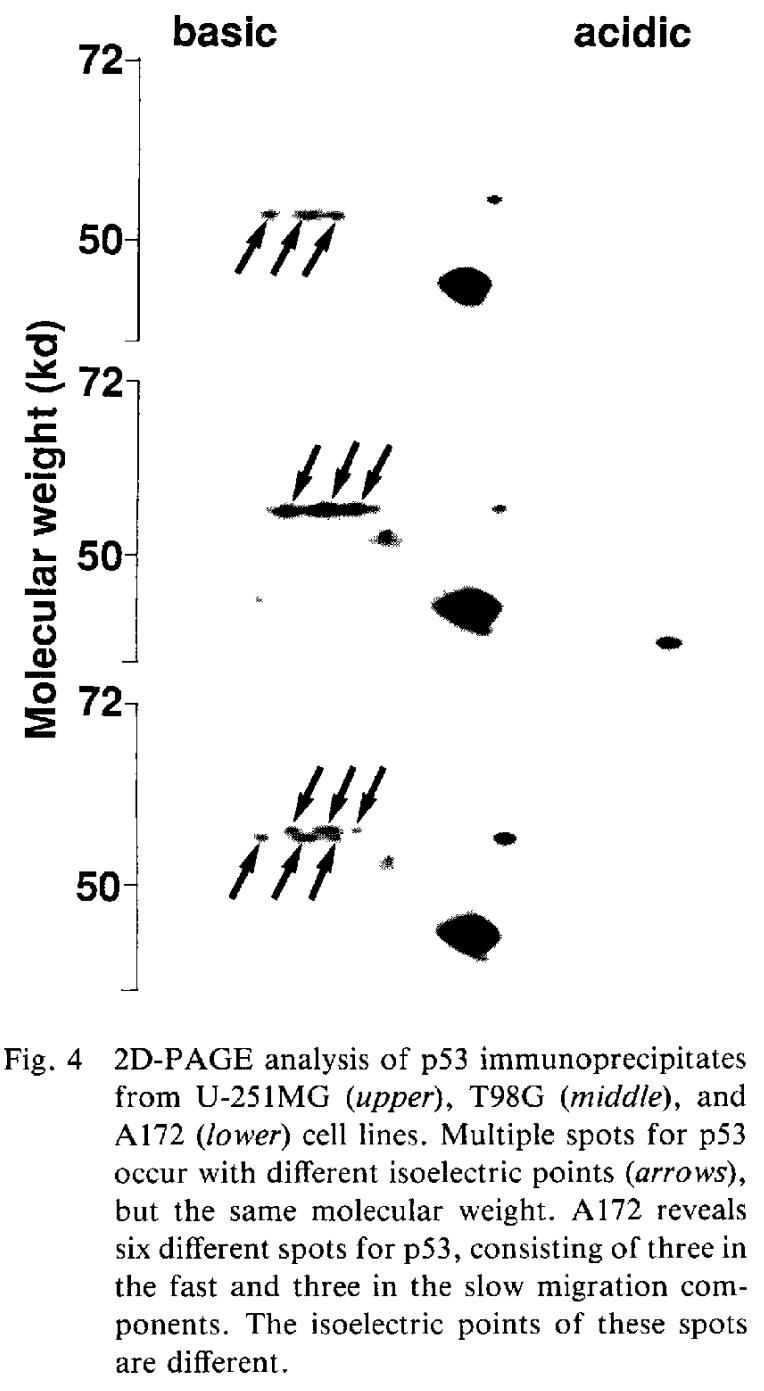

Chase $0 \quad 30 \quad 60 \quad 180 \quad 0 \quad 30 \quad 60180$

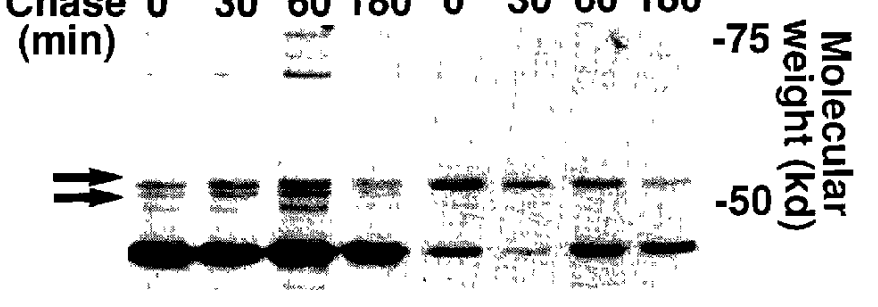

Fig. 5 Pulse-chase analysis of p53 in A172 (left) and T98G (right) cells. Both p53 doublet bands of A172 (arrows) and the single band of T98G continue to maintain radioactivity even after 60 minutes of chase, indicating the prolonged half-life of $p 53$ in these cells.

\section{Pulse-chase analysis}

The pulse-chase analysis was performed to determine whether the intense expression of $\mathrm{p} 53$ in glioma 
cells is due to its increased half-life. Figure 5 shows both p 53 doublet bands of A172 cells and the single band of T98G cells maintained radioactivity even after 60 minutes, suggesting marked prolongation of the half-life of p53 in these cells.

\section{PCR-SSCP analysis}

Regions of the human p53 gene (Fig. 1) were selectively amplified by PCR using each pair of primers. As shown in Fig. 6, mobility shifts of the DNA fragments, which reflected the conformational changes of the p53 gene secondary to nucleotide substitutions or deletions, were observed in exon 5
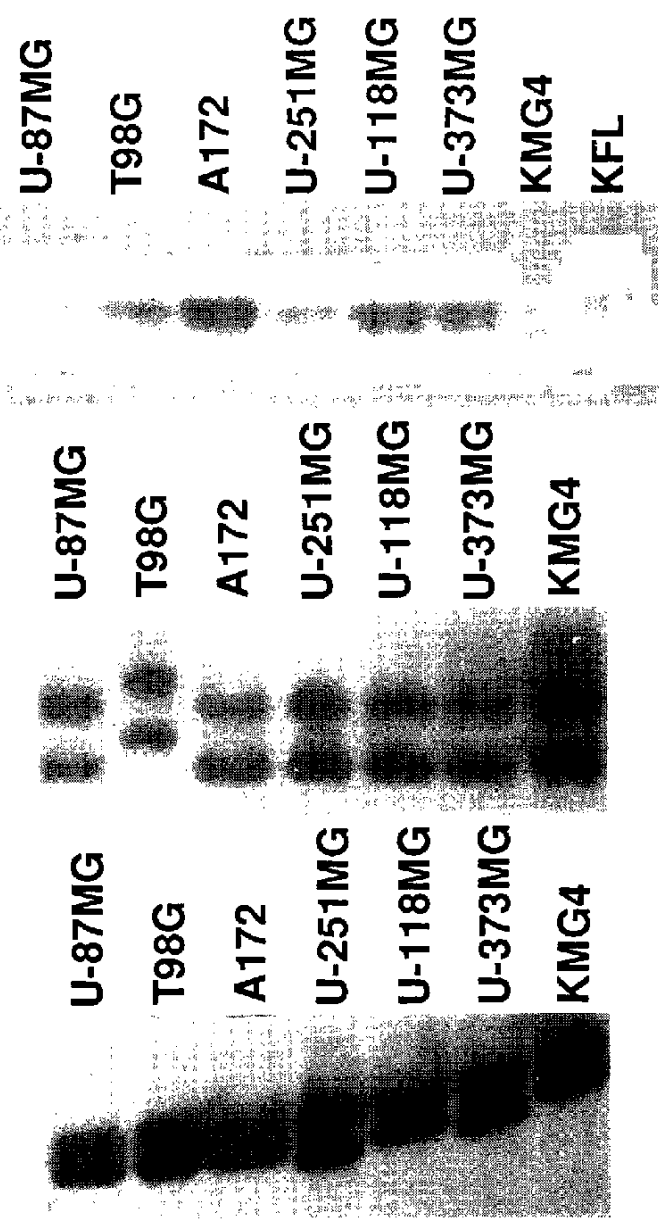

Fig. 6 PCR-SSCP analysis of conserved domains of the p53 gene in human glioma cell lines. Each lane consists of two bands, which are complementary single strands of DNA fragments. Mobility shift is considered due to nucleotide substitution or deletion. The p53 gene displays altered mobility bands for KMG4 in exon 5 ( $u p$ per), T98G in exon 7 (middle), and U-251MG and $\mathrm{U}-373 \mathrm{MG}$ in exon 8 (lower).

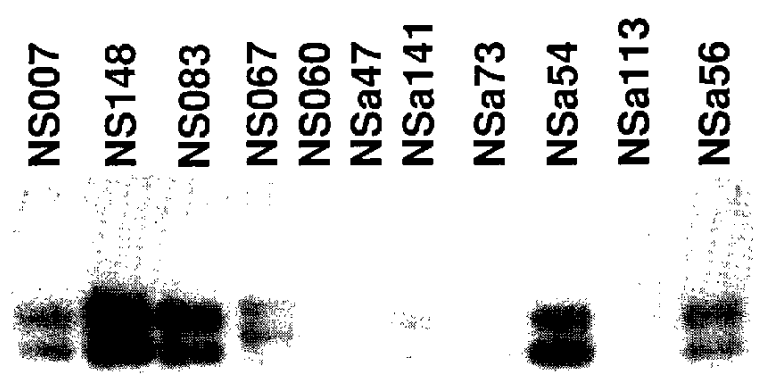

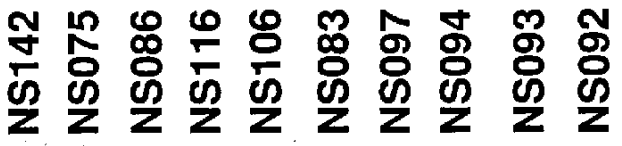
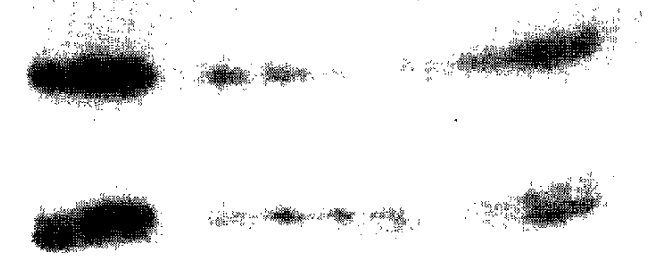

Fig. 7 PCR-SSCP analysis of the biopsied specimens. upper: For exon 7 of the p53 gene, NS067, a case of glioblastoma, shows aberrant bands due to nucleotide substitution or deletion. lower: For exon 8 of the p 53 gene, $\mathrm{NS} 083$, a case of medulloblastoma, also reveals abnormal bands indicating mutation of the p53 gene.

Table 2 Alteration in the p53 gene detected by PCRSSCP analysis

\begin{tabular}{lrc} 
Histology & $\begin{array}{c}\text { No. of cases } \\
\text { tested }\end{array}$ & $\begin{array}{c}\text { No. of cases } \\
\text { showing mutation }\end{array}$ \\
\cline { 2 - 3 } Astrocytoma & 8 & $3(38 \%)$ \\
Glioblastoma & 16 & $5(31 \%)$ \\
Medulloblastoma & 5 & $1(20 \%)$ \\
\hline \multicolumn{1}{c}{ Total } & 29 & $9(31 \%)$ \\
\hline
\end{tabular}

from KMG4 cells, in exon 7 from T98G cells, and in exon 8 from both U-251MG and U-373MG cells. The DNA fragments prepared by PCR from the nine formalin-fixed tumor tissues ( 3 astrocytomas, 5 glioblastomas, and 1 medulloblastoma) also displayed mobility shifts in either exon 7 or 8 of the p53 gene (Fig. 7). However, no altered mobility was observed in other biopsied specimens examined. Table 2 summarizes the results obtained from 29 surgical specimens. 


\section{Discussion}

This study clearly demonstrated heterogeneities in the conformation and expression of $\mathrm{p} 53$ in cultured human glioma cells. Immunocytochemical examination of p53 expression revealed positive nuclear staining in six of seven glioma cell lines. SDS-PAGE analysis showed unequivocal heterogeneity in the migration rate of $\mathrm{p} 53$ bands. Previous studies ${ }^{31,48)}$ indicate that the mutant forms of p53 may be distinguished from the wild-type p53 by abnormal migration on polyacrylamide gels, and by an increased half-life causing accumulated mutant proteins in the nucleus. Even a single amino acid change in p53 may cause an abnormal migration on SDS-PAGE or prolongation of half-life. ${ }^{6)}$ Indeed, elevated levels and prolonged half-life of p53 frequently occur in transformed cell lines. ${ }^{(0,30)}$ The half-life of the wild-type p53 is 6-30 minutes. ${ }^{17}$ The pulse-chase analysis clearly revealed the increased half-life of p53 expressed in both A 172 and T98G cells, presumably due to genetic alterations in the p53 gene. Nucleotide substitutions or deletions in exon 5,7 , or 8 of the p53 gene were successfully detected by PCR-SSCP analysis in four of seven $(57 \%)$ glioma cell lines. Substitutions of amino acids in the conserved domains of p53 may result in loss of function and prolongation of half-life, or impairment of the autoregulation of p53. The present study, of course, cannot exclude the presence of subtle alterations in other coding or promoter regions of the p53 gene in the other three cell lines.

Multiple subspecies of $\mathrm{p} 53$ with different isoelectric points were observed by 2D-PAGE, though little is known about their structural properties or behavioral activities. However, differential phosphorylation of p53 is most likely since a recent study has shown that three serine residues of human p53 are phosphorylated at the 309,315 , and 386 codons. Interestingly, serine- 315 is phosphorylated by $\mathrm{p} 60-\mathrm{cdc} 2$ and cyclin B-cdc 2 complex, ${ }^{4)}$ and this is considered essential for controlling the cell cycle. In the present study, the electrophoretic patterns of $\mathrm{p} 53$ were similar for wild and mutant types, indicating that the observed mutations in the conserved domains do not affect the phosphorylation of p53.

Biological potential differs fundamentally between in vivo and in vitro populations of glioma cells. Therefore, we cannot conclude whether the altered structure and expression of the $\mathrm{p} 53$ gene are primary characters of gliomas or a secondary sequence in established glioma cell lines. However, we did detect mutations of the p53 gene in the biopsied specimens of various neuroepithelial tumors: three of eight
$(38 \%)$ astrocytomas, five of $16(31 \%)$ glioblastomas, and one of five $(20 \%)$ medulloblastomas. These results strongly suggest that mutations of the p53 gene may be closely related to the tumorigenesis in one third of human neuroepithelial tumors. In contrast, medulloblastoma infrequently displays p53 gene mutation. ${ }^{41)}$

The role of tumor suppressor gene in the oncogenesis of human glioma has not yet been studied in detail. ${ }^{11,21,29)}$ Recently, allelic deletions of chromosome $17 \mathrm{p}$ have been found in certain human astrocytic tumors ${ }^{13,19,22,23,50)}$ and in other tumors ${ }^{5,12,20,42,43)}$ such as lung and colorectal cancers. Genetic analyses of these tumors have demonstrated deletions or mutations of the p53 gene located on chromosome $17 \mathrm{p}$. Although the function of $\mathrm{p} 53$ in non-transformed cells is not yet well understood, it is generally believed that the wild-type p53, like the retinoblastoma gene product, acts as a tumor suppressor probably by negative regulation of cell division. ${ }^{2,7}$, 14,16,34) Gene transfection studies showed that the wild-type p 53 gene inhibited the transforming ability of mutant p53 in rat embryo fibroblasts. ${ }^{14,16)}$ In contrast, microinjected MoAbs against p53 inhibited the transition of Swiss $3 T 3$ cells from $G_{0}$ to $S$ phase, but had no effect on the progression of these cells from $\mathrm{S}$ phase to mitosis. ${ }^{33)}$ Therefore, wild-type p53 is probably an important negative regulator of cell cycle, and mutations of the p53 gene result in loss of suppression or co-operate with other oncogenes such as ras or myc to stimulate neoplastic growth.

Certain oncogenes are frequently activated or amplified in human gliomas. ${ }^{3,24,27,45)}$ We cannot now explain the pathogenic relationship between the altered structure of the p53 gene and the activation of certain oncogenes such as erbB-1 in glial tumors. Probably most of the activation or amplification of oncogenes in glioma are due to a secondary event associated with the neoplastic transformation of glial cells. Recently, germ-line mutations of the p53 gene have been shown to underlie the Li-Fraumeni syndrome which predisposes the development of brain tumor and leukemia, in addition to breast cancer, sarcoma, and other malignancies. ${ }^{28,44,49)}$ In fact, mutations of the p53 gene appear to be the most common genetic alterations in human cancers. For example, an interesting case of ependymoma was associated with a germ-line mutation of the p53 gene, ${ }^{351}$ suggesting that the p53 mutations predispose intracranial malignancy. However, further investigation including locating the mutations or deletions within the p53 gene of glioma tissues are necessary to define the causal relationship between the alterations in the p53 gene and transformation of glial cells to 
the neoplastic phenotype.

\section{Acknowledgment}

The authors gratefully acknowledge the excellent technical assistance of Mrs. Sachiko Akiyama and Mrs. Yumiko Ohishi.

\section{References}

1) Baker SJ, Fearon ER, Nigro JM, Hamilton SR, Preisinger AC, Jessup JM, van Tuinen P, Ledbetter DH, Barker DF, Nakamura Y, White R, Vogelstein B: Chromosome 17 deletions and p53 gene mutations in colorectal carcinomas. Science 244: 217-221, 1989

2) Baker SJ, Markowitz S, Fearon ER, Willson JKB, Vogelstein B: Suppression of human colorectal carcinoma cell growth by wild-type p53. Science 249 : $912-915,1990$

3) Bigner SH, Wong AJ, Mark J, Muhlbaier LH, Kinzler KW, Vogelstein B, Bigner DD: Relation between gene amplification and chromosomal deviations in malignant human gliomas. Cancer Genet Cytogenet 26: 165-170, 1987

4) Bischoff JR, Friedman PN, Marshak DR, Prives C, Beach D: Human p53 is phosphorylated by p60-cdc2 and cyclin B-cdc2. Proc Natl Acad Sci USA 87: 47664770,1990

5) Bressac $B$, Galvin $\mathrm{KM}$, Liang $\mathrm{TJ}$, Isselbacher $\mathrm{KJ}$, Wands JR, Ozurk M: Abnormal structure and expression of p53 gene in human hepatocellular carcinoma. Proc Natl Acad Sci USA 87: 1973-1977, 1990

6) Buchman VL, Chumakov PM, Ninkina NN, Samarina OP, Georgiev GP: A variation in the structure of the protein-coding region of the human p 53 gene. Gene 70: 245-252, 1988

7) Chen PL, Chen Y, Bookstein R, Lee WH: Genetic mechanism of tumor suppression by the human p 53 gene. Science 250: 1576-1580, 1991

8) Chen PL, Neubaur A, Kurisu W, Waldman FM, Ljung BM, Goodson W III, Goldman ES, Moore D II, Balazs M, Liu E, Mayall BH, Smith HS: Loss of heterozygosity on the short arm of chromosome 17 associated with high proliferative capacity and DNA aneuploidy in primary human breast cancer. Proc Natl Acad Sci USA 88: 3847-3851, 1991

9) Crawford LV: The 53,000-dalton cellular protein and its role in transformation. Int Rev Exp Pathol 25: 150,1983

10) Crawford LV, Pim DC, Gurney EG, Goodfellow P, Taylor PJ: Detection of a common feature in several human tumor cell lines - a 53,000-dalton protein. Proc Natl Acad Sci USA 78: 41-45, 1981

11) Cusimano MD: An update on the cellular and molecular biology of brain tumors. Can J Neurol Sci 16: 22-27, 1989

12) Davidoff AM, Humphrey PA, Iglehart JD, Marks JR: Genetic basis for p53 overexpression in human breast cancer. Proc Natl Acad Sci USA 88: 50065010,1991

13) El-Azouzi M, Chung RY, Farmer GE, Martuza RL, Black PMcL, Rouleau GA, Hettlich C, HedleyWhite ET, Zervas NT, Panagopoulos K, Nakamura Y, Gusella JF, Seizinger BR: Loss of distinct region on the short arm of chromosome 17 associated with tumorigenesis of human astrocytomas. Proc Natt Acad Sci USA 86: 7186-7190, 1989

14) Eliyahu D, Michalovitz DM, Eliyahu S, PinhasiKimhi O, Oren M: Wild-type p53 can inhibit oncogene-mediated focus formation. Proc Natl Acad Sci USA 86: 8763-8767, 1989

15) Fearon ER, Vogelstein B: A genetic model for colorectal tumorigenesis. Cell 61: 759-767, 1990

16) Finlay CA, Hinds PW, Levine AJ: The p 53 proto-oncogene can act as a suppressor of transformation. Cell 57: 1083-1093, 1990

17) Finlay CA, Hinds PW, Tan T-H, Eliyahu D, Oren $\mathrm{M}$, Levine AJ: Activating mutations for transformation by 553 produce a gene product that forms an hsc70-p 53 complex with an altered half-life. Mol Cell Biol 8: 531-539, 1988

18) Fujimoto M, Fults DW, Thomas GA, Nakamura $Y$, Heilbrun MP, White R, Story JL, Naylor SL, KaganHallet KS, Sheridan PJ: Loss of heterozygosity on chromosome 10 in human glioblastoma multiforme. Genomics 4: 210-214, 1989

19) Fults DW, Tippets RH, Thomas GA, Nakamura $Y$, White R: Loss of heterozygosity for loci on chromosome $17 \mathrm{p}$ in human malignant astrocytoma. Cancer Res 49: 6572-6577, 1989

20) Gaidana G, Ballerini P, Gongo JZ, Inghirami G, Neri A, Newcomb EW, Magrath IT, Knowles DM, Dalla-Favera R: p53 mutations in human lymphoid malignancies: Association with Burkitt lymphoma and chronic lymphocytic leukemia. Proc Natl Acad Sci USA 88: 5413-5417, 1991

21) Hollstein M, Sidransky D, Vogelstein B, Harris CC: p53 mutations in human cancers. Science 253: 49-53, 1991

22) James CD, Carlbom E, Dumanski J, Hansen M, Nordenskjoid M, Collins VP, Cavene WK: Clonal genomic alterations in glioma malignancy stages. Cancer Res 48: 5546-5551, 1988

23) James $C D$, Carlbom E, Nordenskjold $M$, Collins VP, Cavenee WK: Mitotic recombination of chromosome 17 in astrocytomas. Proc Natl Acad Sci USA 86: 2858-2862, 1989

24) Kinzler $\mathrm{KW}$, Bigner SH, Bigner DD, Trent JM, Law ML, O'Brien SJ, Wong AJ, Vogelstein B: Identification of an amplified, highly expressed gene in human glioma. Science 236: 70-73, 1987

25) Levine AJ, Momand J: Tumor suppressor genes: The p53 and retinoblastoma sensitivity genes and gene products. Biochim Biophys Acta 1032: 119-136, 1990

26) Levine AJ, Momand J, Finlay CA: The p53 tumor suppressor gene. Nature 351: 453-456, 1991

27) Libermann TA, Nusbaum HR, Razon N, Kris R, Lax 
I, Soreq H, Whittle N, Waterfield MD, Ullrich A, Schlessinger J: Amplification, enhanced expression and possible rearrangement of EGF receptor gene in primary human brain tumors of glial cell origin. Nature 313: 144-147, 1985

28) Malkin D, Li FP, Strong LC, Fraumeni JF, Nelson CE, Kim DH, Kassel J, Grayka MA, Bischoff FZ, Tainsky MA, Friend SH: Germ line p53 mutations in a familial syndrome of breast cancer, sarcomas and other neoplasms. Science 250: 1233-1238, 1990

29) Mashiyama S, Murakami $Y$, Yoshimoto $T$, Sekiya $T$, Hayashi $K$ : Detection of p53 gene mutations in human brain tumors by single-strand conformation polymorphism analysis of polymerase chain reaction products. Oncogene 6: 1313-1318, 1991

30) Matlashewski GJ, Banks L, Pim D, Crawford L: Analysis of human p53 proteins and mRNA levels in normal and transformed cells. Eur $J$ Biochem 154: 665-672, 1986

31) Matlashewski GJ, Tuck S, Pim D, Lamp P, Schneider J, Crawford LV: Primary structure polymorphism at amino acid residue 72 of human p53. Mol Cell Biol 7: 961-963, 1987

32) McBride OW, Merry D, Givol $D$ : The gene for human p53 cellular tumor antigen is located on chromosome 17 short arm (17p13). Proc Natl Acad Sci USA 83: 130-134, 1986

33) Mercer WE, Avignolo C, Baserga R: Role of p 53 protein in cell proliferation as studied by microinjection of monoclonal antibodies. Mol Cell Biol 4: 276-281, 1984

34) Mercer WE, Shields MT, Lin D, Appella E, Ullrich $\mathrm{SJ}$ : Growth suppression induced by wild-type p53 protein is accompanied by selective down-regulation of proliferating-cell nuclear antigen. Proc Natl Acad Sci USA 88: 1958-1962, 1991

35) Metzger AK, Sheffield VC, Duyk G, Daneshvar L, Edwards MSB, Cogen PH: Identification of a germline mutation in a patient with an intracranial ependymoma. Proc Natl Acad Sci USA 88: 7825-7829, 1991

36) Nigro JM, Baker SJ, Preisinger AC, Jessup JM, Hostetter R, Cleary K, Bigner SH, Davidson N, Baylin S, Devilee P, Glover T, Collins FS, Weston A, Modali R, Harris CC: Mutations in the p53 gene occur in diverse human tumour types. Nature 342 : $705-$ 708,1989

37) Orita $M$, Iwahana $H$, Kanazawa $H$, Hayashi $K$, Sekiya $T$ : Detection of polymorphism of human DNA by gel electrophoresis as single-strand conformation polymorphisms. Proc Natl Acad Sci USA 86: 2766-2770, 1989

38) Parada LF, Land H, Weinberg RA, Wolf D, Rotter $\mathrm{V}$ : Cooperation between gene encoding p53 tumor antigen and ras in cellular transformation. Nature 312 :
649-651, 1984

39) Raffel C, Gilles FE, Weinberg KI: Reduction to homozygosity and gene amplification in central nervous system primitive neuroectodermal tumors of childhood. Cancer Res 50: 587-591, 1990

40) Saiki RK, Geifand DH, Stoffel S, Schale SJ, Higuchi R, Hoen GT, Mullis KB, Erlich H: Primer-directed enzymatic amplification of DNA with a thermostable DNA polymerase. Science 239: 487-491, 1988

41) Saylors RL III, Sidransky D, Friedman HS, Bigner $\mathrm{SH}$, Bigner DD, Vogelstein B: Infrequent p53 gene mutations in medulloblastomas. Cancer Res 51: 4721-4723, 1991

42) Shirasawa $S$, Urabe $K$, Yanagawa $Y$, Toshitani $K$, Iwama $T$, Sasazuki T: p53 gene mutations in colorectal tumors from patients with familial polyposis coli. Cancer Res 51: 2874-2878, 1991

43) Sidransky D, Eschenbach AV, Tsai YC, Jones P, Summerhayes I, Marshall F, Paul M, Green P, Hamilton SR, Frost P, Vogelstein B: Identification of p53 gene mutations in bladder cancers and urine samples. Science 252: 706-709, 1991

44) Srivastava S, Zou Z, Pirollo K, Blattner W, Chang $\mathrm{EH}$ : Germ-line transmission of a mutated $\mathrm{p} 53$ gene in a cancer-prone family with Li-Fraumeni syndrome. Nature 348: 747-749, 1990

45) Tabuchi K: Oncogene-related products of glioma cells. Shinkei Kenkyu No Shinpo 31: 1015-1022, 1987 (in Japanese)

46) Takahashi T, Nau MM, Chiba I, Birrer MJ, Rosenberg RK, Vinocour M, Levitt M, Pass H, Dazdar AF, Minna JD: p53: A frequent target for genetic abnormalities in lung cancer. Science 246: 491-494, 1989

47) Thomas GA, Raffel C: Loss of heterozygosity on 6q, $16 \mathrm{q}$, and $17 \mathrm{p}$ in human central nervous system primitive neuroectodermal tumors. Cancer Res 51: 639-643, 1991

48) Thomas R, Kaplan L, Reich N, Lane DP, Levine AJ: Characterization of human p53 antigens employing primate specific monoclonal antibodies. Virology 131: 502-512, 1983

49) Vogelstein B: A deadly inheritance. Nature 348: 681682,1990

50) Watanabe K, Nagai M, Wakai S, Arai T, Kawashima $\mathrm{K}$ : Loss of constitutional heterozygosity in chromosome 10 in human glioblastoma. Acta Neuropathol (Berl) 80: 251-254, 1990

Address reprint requests to: K. Tabuchi, M.D., Department of Neurosurgery, Saga Medical School, 5-1-1 Nabeshima, Saga 849, Japan. 